\title{
Review of hospital plastic waste management strategies for Pakistan
}

\author{
Yasir Qayyum Gill' • Mudasar Khurshid ${ }^{1}\left[\right.$ - Umer Abid ${ }^{1} \cdot$ Muhammad Wajid ljaz $^{2}$
}

Received: 29 August 2021 / Accepted: 20 November 2021 / Published online: 1 December 2021

(c) The Author(s), under exclusive licence to Springer-Verlag GmbH Germany, part of Springer Nature 2021

\begin{abstract}
Healthcare waste management is considered one of the biggest challenges that the world is going to face in the future. This threat is becoming reality owing to the worldwide sharp rise in healthcare waste generation particularly during the current COVID-19 pandemic. Like many other environmental crises, hospital plastic waste management is an area that got very little attention despite being highlighted in the literature, local media, as well as in international electronic and print media. This mini-review was conducted to assess the overall prevailing situation regarding hospital plastic waste management in Pakistan. Several illegal and unethical activities have been observed regarding hospital plastic waste management in Pakistan which includes unhygienic recycling, repacking of used hospital plastic items, open dumping on land, and disposal of hospital plastic waste in the ocean. To improve these conditions, suggestions have been made regarding the better management of hospital plastic waste.
\end{abstract}

Keywords Hospital plastic waste $\cdot$ COVID-19 waste $\cdot$ Illegal recycling of hospital waste $\cdot$ Mixed plastic crosslinking

\section{Introduction}

\section{Definition of healthcare waste}

Healthcare waste $(\mathrm{HCW})$ is a term used for all types of waste produced by healthcare facilities, research centers, and laboratories during the diagnosis, treatment, and immunization of human beings and animals (Khan et al. 2010; Pieper et al. 2017). Several different sources of healthcare waste have been identified which include hospitals, health clinics, medical camps, veterinary services, medical laboratories,

Responsible Editor: Lotfi Aleya

Yasir Qayyum Gill yqgill@uet.edu.pk

Mudasar Khurshid mudasarkurshid1@gmail.com

Umer Abid

umerabid59@gmail.com

Muhammad Wajid Ijaz

wajidijaz331@gmail.com

1 Department of Polymer and Process Engineering, University of Engineering and Technology, G. T. Road, PO Box 54890, Lahore, Pakistan

2 Environmental Protection Agency, Government of the Punjab, Lahore, Pakistan research centers, blood banks, mortuaries, and home-based healthcare (Prem Ananth et al. 2019).

Alternatively, different expressions have been used for healthcare waste which includes hospital waste (S. Ali et al. 2015; Altin et al. 2003; Arshad et al. 2011; Qadir et al. 2002; Toheed et al. 2005; Zeeshan et al. 2009), medical waste (Alwabr et al. 2010; Birpinar et al. 2011; El-Ramady et al. 2011; Komilis et al. 2012; Mohee 2014; Patwary et al. 2014), biomedical waste (Badni and Dharmashree 2016; Gautam et al. 2016; Tiwari 2018), and infectious waste (Lee et al. 2021), etc.

\section{Composition of HCW}

According to $\mathrm{WHO}$, healthcare waste can be categorized into two main classes of non-hazardous and hazardous wastes. The non-hazardous waste consists of 75 to $90 \%$ of total healthcare waste, while the remaining 10 to $25 \%$ of the waste is considered hazardous waste (Pieper et al. 2017). Hazardous waste has been classified into two major categories, i.e., infectious (10\%) and chemical (5\%) wastes. Non-hazardous waste is just like general waste and does not require any special handling and treatment for its disposal.

On the other hand, hazardous waste is regulated and requires special treatment and handling before its final disposal (Lee et al. 2004). Six subcategories of hazardous waste 
have been identified in the healthcare sector, namely, infectious waste, sharps waste, pathological waste, pharmaceutical and cytotoxic wastes, chemical waste, and radioactive waste (Pieper et al. 2017).

\section{Growth of HCW}

Worldwide $\mathrm{HCW}$ generation rate has multiplied significantly in the last few decades on accounts of several factors, i.e., world population growth, increase in healthcare facilities, preference for disposable medical devices, and other socialeconomic factors (Khan et al. 2019). This growth rate is more prominent in developed countries as compared to the developing nations due to innovative medical practices, the rise of single-use disposable medical devices, and safety measures (Ali et al. 2016; Oweis et al. 2005). The production rate of healthcare waste per hospital bed per day is more than double in high-income countries as compared to lowincome countries.

The USA alone generates 3.36 million tons of medical waste per year and has spent around 3.7 billion US dollars to dispose it of (Azouz et al. 2019; Mahmood et al. 2011). Around 0.8 million tons of waste is daily produced from the healthcare sector in Pakistan which is the sixth most populous nation in the world and considered as one of the rapidly urbanizing and population growing countries in the Asian region (Ali et al. 2016; Zeeshan et al. 2018).

\section{Why is HCW management important?}

Healthcare waste management is of utmost importance for proper treatment and disposal of waste owing to the presence of the infection-causing microorganism in healthcare waste, which has the potential of infecting the patients, healthcare staff, and the public. According to WHO, improper healthcare waste management practices have caused 33,800 HIV infections, 1.7 million hepatitis B (HBV) infections, and 315,000 hepatitis C (HCV) infections in 2010. Persons in direct contact with the waste (hospital cleaning staff and scavengers involved in illegal scavenging) have a higher risk of developing diseases like HIV (0.3\%), HBV (30\%), and HCV (1.8\%) (Amsalu et al. 2016; Arafa and Eshak 2020). According to WHO/UNICEF statistics, out of 560,000 healthcare facilities, $40 \%$ lack proper healthcare management in 125 countries and this condition is even worse in under-developing countries where only $27 \%$ of facilities have essential healthcare management (World Health Organization (WHO) 2019b).

To improve healthcare plastic waste management, a few suggestions and a crosslinking method will be presented in the current study which will help to stop the illegal recycling of contaminated healthcare plastic waste in developed countries, especially Pakistan.

\section{Importance of hospital plastic waste management}

\section{Types of medical devices}

Traditionally, materials like glass, metals, ceramics, wood, and stone were used to accommodate the needs of the healthcare sector in the form of medical devices. For example, intravenous (IV) bottles of glass, tubing made of rubber, and surgical instruments of metals were used widely until the 1930s when IV bags of polyvinyl chloride (PVC), tubing of PVC, and catheters made out of silicone were introduced (Modjarrad and Ebnesajjad 2003). Nowadays, polymers, rubbers, and polymer composite-based materials have occupied the market in the field of food packaging, medical instruments, furniture, automotive, health care instruments, and various other applications (Abid et al. 2012; Adeosun et al. 2013; Gill et al. 2018, b, c; Salernitano and Migliaresi 2020; Zagho et al. 2021a; Zeng et al. 2021). The utilization of plastics in medical devices includes simple tools such as spatulas, syringes, and dressings along with complex instruments, i.e., MRI, $\mathrm{X}$-ray machine, surgical devices, etc. Two major categories of medical equipment can be classified as non-disposable and disposable.

Diagnostic and imaging instruments, dental and surgical implants, and prosthetics are examples of non-disposable devices while simple items such as syringes, gloves, IV bags, tubes, catheters, and dressings are some common examples of disposable devices/accessories. In the case of non-disposable devices, the materials used are the ones which possess high mechanical and physical properties to make them long-lasting. Non-disposable devices which come in contact with living human tissues should be inert or biocompatible depending on the nature of the implant (Sastri 2013).

On the other hand, disposable medical devices are made of commodity plastics that have excellent mechanical properties and possess the ease of processing according to the desired design and application of the device. Besides these, they should have the capability of sterilization and should be cost-effective to replace the traditionally used costly materials.

\section{Share of plastics in the medical device market}

Commodity plastics that approximately hold $70 \%$ market of disposable medical devices are polystyrene (PS), polypropylene (PP), polyethylene (PE), and PVC. Similarly, engineering, high temperature, and thermoplastic elastomers are also being used in high-end medical applications (Fig. 1) (Sastri 2013). 


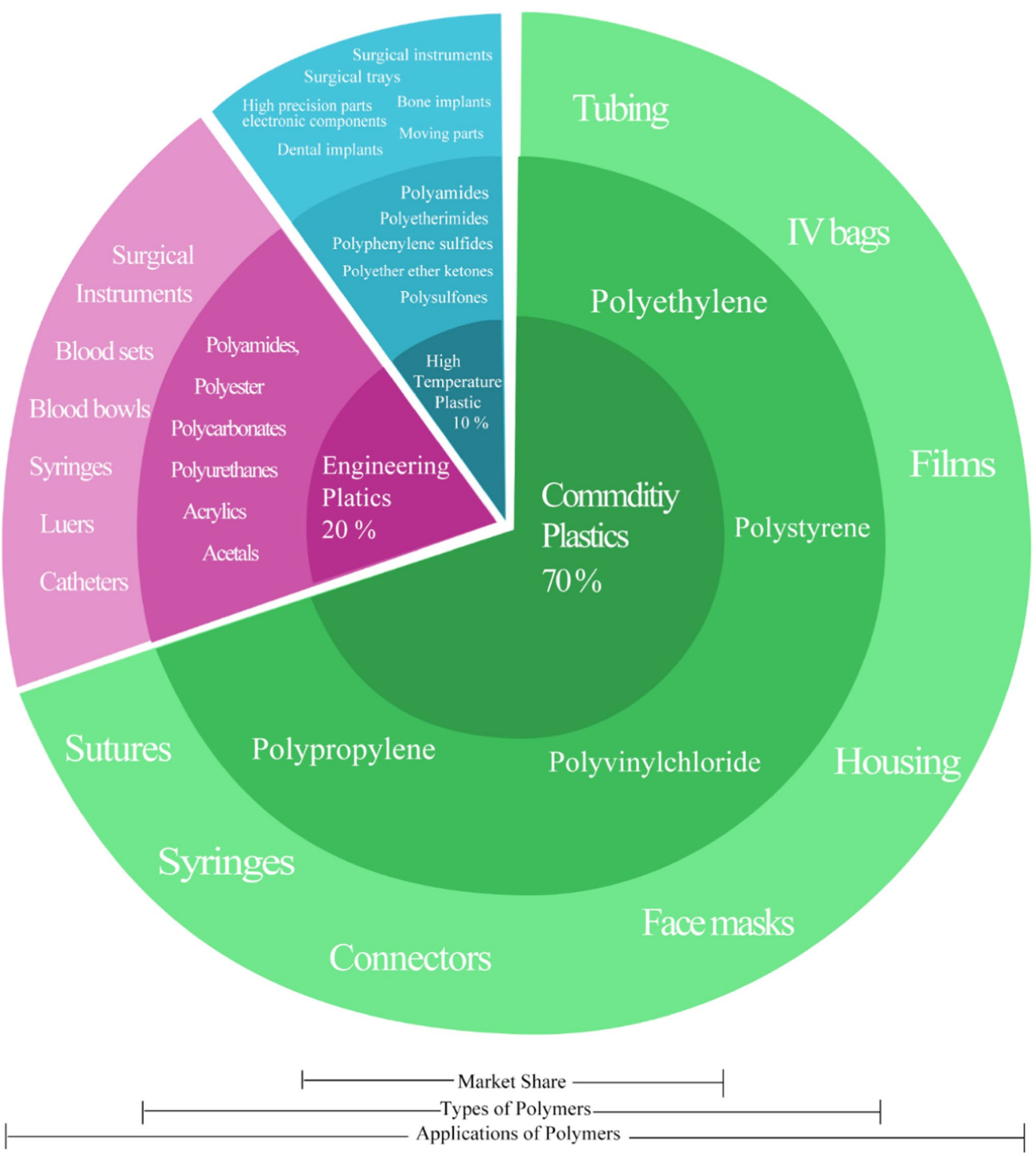

Fig. 1 Share, types, and applications of plastics in the medical device industry

\section{Share of plastics in HCW}

Physical composition analysis has revealed that the major components of hospital waste are plastic, textile, cardboard/ paper, glass, food, and other organic and inorganic materials. The percentages of these components vary according to the country and type of hospital. Even in the same hospital, these components vary based on the nature of the departments/ward present in the hospital (Altin et al. 2003; Alwabr et al. 2016; Mohee 2005; Voudrias et al. 2012).

Plastic is considered as one of the main components of healthcare waste due to the great usage of disposable plastic 
items in hospitals (Munir et al. 2014). The average percentage content in both types of wastes (hazardous and nonhazardous) varies depending upon the category of hospital and country in which the hospital is situated (Table 1).

There are different types of plastic present in healthcare waste in form of different disposable products, packaging, and medical instruments. These products are made up of a single type of plastic and a mixture of plastics or a combination of plastics and other materials (paper, aluminum, etc.)

\section{Legislations regarding hospital waste management}

To improve healthcare management in Pakistan, Hospital Waste Management (HWM) Rules (2005) have been introduced. They are operated under the Environmental Protection Act (PEPA) of 1997 of Pakistan and guidelines laid down by WHO for the establishment of healthcare waste management in healthcare facilities. HWM rules (2005) define different types of wastes present in healthcare waste (infectious waste, chemical waste, genotoxic waste, pathological waste, and non-risk waste, etc.) and specify a waste management plan. Similar to the HWM rules 2005, the Environment Protection Department of Punjab has legislated its own Punjab Hospital Waste Management Rules (PHWM), 2014 (EPD 2014).
Fundamental steps of adequate waste management include segregation, collection, transportation, treatment, and safe disposal (World Health Organization 2a) (Fig. 2019a).

According to the PHWM, segregation of waste is required to be done at the point of source in hospitals by healthcare staff. The risk waste needed to be placed in separate containers lined with yellow color plastic bags which are removed when they are three-quarters filled and marked with useful information like date, point of source, quantity, and biohazard sign.

Sharp waste is required to be placed in a metal or plastic sealed container that then can be placed in a yellow bag if it is required to be incinerated. Similarly, small quantities of pharmaceutical waste are placed inside the yellow plastic bag. In the case of radioactive waste, it can be placed in a yellow bag or white bag (designated for non-risk waste) depending upon its infectious or non-infectious nature. Non-risk waste is placed in a separate container lined with a white plastic bag. For the in-house transportation of hospital waste, three- or four-wheel yellow and white trolleys for risk waste and non-risk waste, respectively, are equipped to transport waste in sealed bags from the collection point to the final storage in hospital premises.

These trolleys should be free from sharp edges and should have ease of unloading and loading capability. For the offsite movement of hospital waste, vehicles and skips provided by the local council should be used to transport risk and non-risk waste separately. Yellow bag waste is needed to

Table 1 Plastic content in healthcare waste depends on the category of hospital and country in which the hospital is situated

\begin{tabular}{|c|c|c|c|c|}
\hline Sr. no & Country & $\begin{array}{l}\text { Plastic content in hazard- } \\
\text { ous waste }(\%)\end{array}$ & $\begin{array}{l}\text { Plastic content in non- } \\
\text { hazardous waste (\%) }\end{array}$ & Type of hospital \\
\hline 1 & Pakistan (Lahore) & 75.9 & 2.3 & Children's hospital (Munir et al. 2014) \\
\hline 2 & Pakistan (Gujranwala) & - & 13.41 & Multiple (Ali et al. 2016) \\
\hline 3 & India & $20-60$ & - & Multiple (Tiwari 2014) \\
\hline 4 & Turkey (Sivas) & 41 & & Multiple (Altin et al. 2003) \\
\hline 5 & Mauritius & - & 22 & Multiple (Mohee 2005) \\
\hline 6 & Taiwan & 29.58 & & Multiple (Li and Jenq 1993) \\
\hline 7 & Peru & 11.75 & & Multiple (Diaz et al. 2008) \\
\hline 8 & Yemen (Sana) & 22 & & Multiple (Alwabr et al. 2016) \\
\hline 9 & Kuwait & & 24 & Multiple (Desai and Mukherji 2001) \\
\hline 10 & Libya & - & 24 & Multiple (Sawalem et al. 2009) \\
\hline 11 & Bangladesh & 20.30 & 6.77 & General (Alam et al. 2008) \\
\hline 12 & Iran (Tabriz) & 35.72 & 16.40 & Multiple (Taghipour and Mosaferi 2009) \\
\hline 13 & USA & 32.64 & 25 & Multiple (Wong et al. 1994) \\
\hline 14 & Australia & & 33 & Multiple (Vinyl Council of Australia 2018) \\
\hline 15 & Italy & 46 & - & General (Pieper et al. 2017) \\
\hline 16 & Romania & 20 & - & Multiple (Bordeianu et al. 2015) \\
\hline 17 & Canada & 14 & - & General (Strashok et al. 2010) \\
\hline
\end{tabular}


Fig. 2 a Overview of hospital waste management (Pieper et al. 2017). b Global demand of PPE during COVID-19 for healthcare workers each month estimated by WHO (Singh et al. 2020) (a)
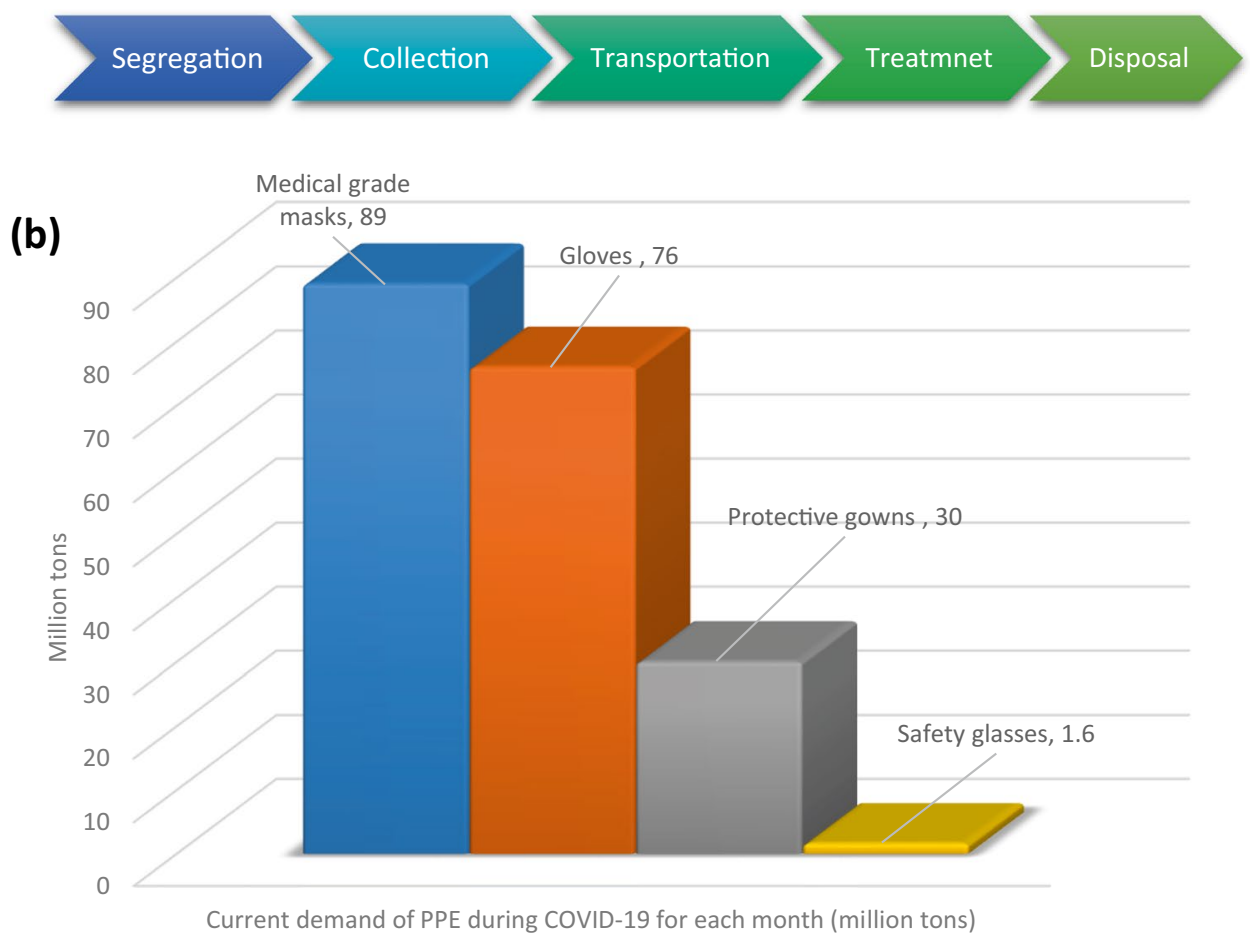

transport at least daily by the staff wearing protective clothing in a vehicle that is free from sharps, capable of easy loading and unloading, and easy cleaning and disinfection.

To ensure safe offsite transportation of the waste, vehicles are required to be equipped with empty waste bags, cleaning tools, protective clothing, and disinfectant to safely manage any spillage. Besides these vehicles, staff should be trained properly to handle yellow bag waste and necessary documentation should be done from point of collection to the final disposal site (EPD 2014).

\section{Current practice in Pakistan}

Pakistan is among the developing Asian countries where inadequate infrastructural arrangements and mishandling of hospital waste are reported frequently (Abdullah et al. 2021; Ahmed Bin Hassan and Mubashar Hassan Zia 2020; Arub et al. 3; Ayub et al. 2019; Khan et al. 2020; Naz et al. 2020). In opposition to the guidelines and rules laid down by WHO and the Ministry of Climate Change (MoCC) of Pakistan, unsafe and illegal disposal of hospital waste is reported in electronic and press media. There have been so many incidents when hospital infectious plastic waste was dumped in the ocean or open land. Figure 2021 contains four such electronic media reports $(\mathrm{e}, \mathrm{f}, \mathrm{g}, \mathrm{h}$ ) related to hospital waste becoming part of the environment and contributing significantly toward environmental pollution.
In a media report, open dumping of hospital waste in Jinnah Postgraduate Medical Centre, Karachi was stated which were accessible for stray birds and scavengers due to non-operational incineration facilities (Faiza Ilyas 2016) (Fig. 3e). Similarly, another electronic media reported an incident littering of Clifton Beach, Karachi, with hospital waste, which included used syringes, blood vial, and broken glass (Drury 2019) (Fig. 3h).

In the same way, unlawful recycling of hospital infectious waste has been reported in international as well as local electronic and press. Infectious waste is being recycled into the making of toys, kitchen foodware, and drinking straws (Jaffery 2013) (Fig. 3a-d). At least 40 recycling units have been identified in Lahore which is involved in illegal and unethical recycling of hospital plastic waste (Randhawa 2003). In addition to the recycling of hospital waste plastic, reusing of used syringes after washing, cleaning, and repacking has also been reported in the literature (Mujeeb et al. 2018).

\section{Impact of COVID-19 on hospital plastic waste}

\section{Worldwide scenario}

According to interim guidelines issued by WHO in the wake of the COVID-19 pandemic, a variety of groups of people, who were nearby infected patients, are at higher risk 

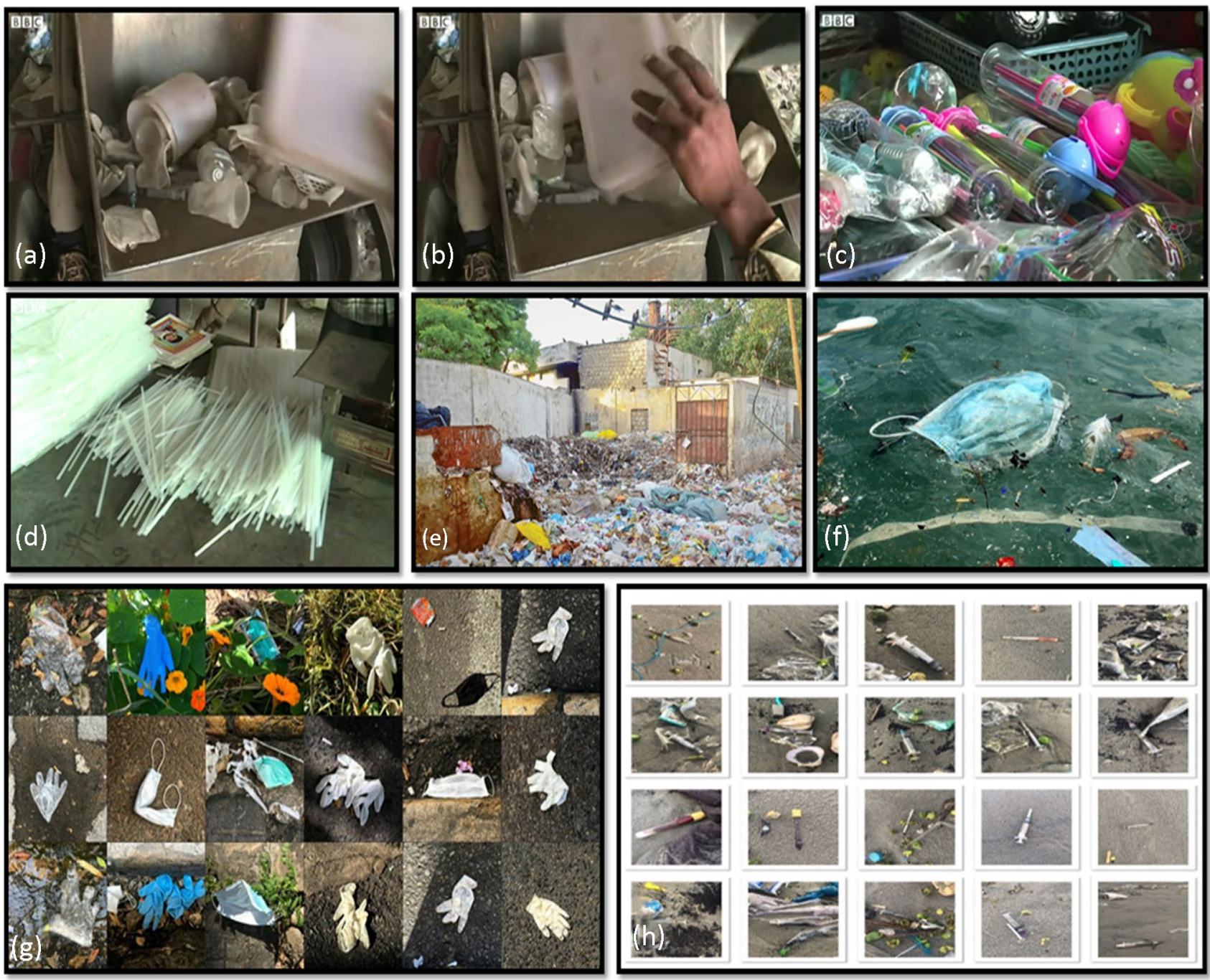

Fig. 3 a-d Illegal recycling of hospital waste in Lahore (Jaffery 2013). e Open dumping of hospital waste in Jinnah Postgraduate Medical Centre, Karachi (Faiza Ilyas 2016). f Surgical mask at Hong

Kong beaches (Bidal 2020). g Used gloves and masks thrown in the city of Beirut (AFP 2020). h Hospital waste littering on Karachi beach (Drury 2019)

of infection as human-to-human contact and human body fluids (saliva droplets) have been identified as a mode of transmission of coronavirus. Personal protection equipment (PPE) is recommended to be worn by these groups of people including healthcare workers, cleaners, visitors, laboratory technicians, caregivers, and ambulance drivers working in the patient room, triage, consultation room, temporary isolation area, etc. (World Health Organization (WHO) 2020a).

Consequently, an exponential rise in the usage of PPEs has been seen during the COVID-19 pandemic (Ammendolia et al. 2021; Das et al. 2b; Haddad et al. 2020; Haque et al. 2020; Yu et al. 2020). According to a model developed by WHO, currently, there is a need for 89 million medical-grade masks, 76 million gloves, 30 million protective gowns, and 1.6 million safety glasses per month for healthcare workers throughout the world as shown in Fig. 2021 (Feinmann 2021;
Rai and Roy 2021; Sangkham 2021; Sarkodie and Owusu 2021).

Similarly, the European Centre for Disease Prevention and Control has estimated that there would be a requirement of 14-24 PPEs sets per confirmed COVID-19 case in healthcare facilities (Feinmann 2020). Italy, the hard-hit country by a coronavirus, would require 1 billion facemasks and 0.5 billion gloves per month after lifting the lockdown according to the estimates made by the Polytechnic University of Turin. It reveals that if $1 \%$ of the masks are disposed of improperly, then there would be 10 million masks (equal to the $40,000 \mathrm{~kg}$ of plastic waste considering the average weight of the mask is $4 \mathrm{~g}$ ) per month littering the environment (Nilay Syam 2020). A similar example of PPEs littering in the capital city of Lebanon was reported in electronic media (AFP 2020) (Fig. 3g). Similarly, used masks were 
seen floating on Hong Kong beaches during the COVID-19 outbreak (Bidal 2020) (Fig. 3f).

Likewise, the healthcare sector in the UK, another country facing the wrath of COVID-19, has consumed 748 million PPEs including masks, aprons, gowns, and gloves during the initial 53-day period of the coronavirus outbreak (Islam 2020).

\section{Situation in Pakistan}

The situation regarding the use of PPEs in Pakistan is not different from other countries. According to the official data provided by the National Disaster Management Authority of Pakistan (NDMA), 141 million of PPEs have been distributed among the hospitals and government departments throughout the country. These PPEs were acquired through direct purchase and in the form of foreign donations. They include facemasks (surgical, N96, KN95, etc.), protective gowns, goggles, gloves, surgical caps, face shields, and shoe covers. Until now, almost 5000 tons of PPE waste has been estimated in government hospitals of Pakistan during this pandemic. Their total quantity, material, weight per item, and the total weight of PPEs are described in Table 2.

This is an estimation of PPE-based medical waste generated by medical staff in government hospitals, but the actual waste generation rate in Pakistan during the coronavirus outbreak would be higher because of the huge consumption of PPEs by general masses and other institutions.

Most of the PPEs are disposable single-use items (Cook 2020), and waste produced by them is considered infectious hospital waste (Wang et al. 2020). Although transmission of COVID-19 through unprotected handling of hospital waste is not reported, yet the waste collection, transportation, treatment, and disposal should be done safely (World Health Organization (WHO) 2020b). That is why it has become inevitable for the world especially developing countries like Pakistan to build and implant better healthcare waste management to control outbreaks of COVID-19.

\section{National action plan (policy) for healthcare supply chain in Pakistan}

The national action plan (NAP) provided by the Ministry of National Health Services, Regulations \& Coordination, Government of Pakistan (Ministry of National Health Services Regulations \& Coordination- Government of Pakistan 2020) serves as the policy document for confirming that all the principles for improvement in the healthcare supply chain are followed that also defines a priority activity list to deal with the healthcare supply chain management. In accordance with the priority activity list, PPEs and other healthcare equipment availability at several designated hospitals is supposed to be ensured. Following the plan, tax exemptions and collaboration of local/private PPEs manufacturers with leading government industrial organizations is one of the key policy interventions considered, so far. Defense Science and Technology Organization (DESTO), Pakistan was subjected to build up the capacity for local manufacturers to prepare masks, surgical gloves, Tyvek suits, and other obligatory equipment. Similarly, the federal taxation institution (Federal Board of Revenue: FBR) in Pakistan granted the exemption on income tax and sales tax to private sector manufacturers of PPEs for ensuring maximum coverage at the reduced prices of PPEs. A ban on the export of medical equipment was imposed to increase the emergency capacity of hospitals. DESTO ensured mass production of ethanol-based hand sanitizers to avoid the spread of coronavirus. Exports of ethanol were subjected to regulations by the Ministry of Commerce to ensure the $100,000 \mathrm{~L} /$ per month availability of pure $99.9 \%$ ethanol for country requirements. These are the parts of policy interventions that have yielded to control the pandemic at the cost of the unprecedented rate of generation of hospital waste and tremendous pressure over the healthcare sector across the globe.
Table 2 Details of PPEs distributed in Pakistan's hospitals and Government departments (NDMA 2020)

\begin{tabular}{lllllc}
\hline Sr. no & PPE & Quantity & Material & $\begin{array}{l}\text { Average weight } \\
\text { per item }(\mathrm{g})\end{array}$ & $\begin{array}{c}\text { Total weight } \\
\text { of items }(\mathrm{kg})\end{array}$ \\
\hline $\mathbf{1}$ & Surgical face mask & $8,052,460$ & Non-woven PP (NPP) & 4 & 322,098 \\
$\mathbf{2}$ & N95 mask & $1,784,403$ & NPP & 12 & 214,128 \\
$\mathbf{3}$ & Protective suits & $1,161,646$ & NPP & 250 & $2,904,115$ \\
$\mathbf{4}$ & Goggles & 145,628 & Polycarbonate & 80 & 116,502 \\
$\mathbf{5}$ & Gloves & $1,492,599$ & Natural latex & 80 & $1,194,079$ \\
$\mathbf{6}$ & Surgical caps & 510,830 & NPP & 15 & 76,624 \\
$\mathbf{6}$ & Gowns & 361,532 & NPP & 60 & 216,919 \\
$\mathbf{7}$ & Face shield & 114,983 & PET & 30 & 34,494 \\
$\mathbf{8}$ & Boot/shoe cover & 478,968 & PE, CPE, PP & 3 & 14,369 \\
\multicolumn{2}{l}{ Total weight of PPE } & & & & $\mathbf{5 , 0 9 3 , 3 3 1}$ \\
\multicolumn{7}{l}{ Total weight of PPE (tons) } & & & $\mathbf{5 0 9 3 . 3 3}$ \\
\hline
\end{tabular}




\section{Suggestions to improve hospital plastic waste management}

\section{Involvement of all stakeholders}

One possible way of safe and efficient handling of hospital plastic waste is the involvement of all stakeholders involved in the production and usage of medical equipment (disposable and non-disposable items). Stakeholders could be the manufacturer, importer, distributor, and healthcare facilities. UK policy for the recycling of plastic waste may be followed for this purpose which divides the share of plastic recycling cost among different stakeholders, i.e., raw material manufacturer (6\%), converter (9\%), fillers $(37 \%$;), the seller $(48 \%)$, secondary provider $(85 \%)$, and service provider (85\%) (Producer Responsibility Obligations (Packaging Waste) Regulations 1997(Producer 1997).

As mentioned earlier, the major portion of hospital plastic waste consists of PP, HDPE, and PVC which are present in the form of syringes, infusion bottles, packaging, tubing, oxygen mask, and other disposable items. PP and HDPE present in hospital waste are mostly of very high quality and up to $90 \%$ of them are worthy enough to be recycled. Nevertheless, they can be recycled into nonfood and non-medical graded items such as coat hangers (Vogt and Nunes 2002). Similarly, IV bags (PVC) which can be $10 \%$ of the total plastic waste are $90 \%$ non-infected and can be recycled (Lee et al. 2014).

\section{Segregation at source}

One of the most crucial steps in the recycling of hospital plastic waste is the proper segregation of waste at the point of source or ward level. It requires the contribution from consumers as well as hospital staff especially the nursing staff.

To make the recycling of hospital plastic waste a successful alternate, the active contribution of medical staff is very important. In this regard, proper training of the nursing staff for the segregation of non-infected waste from infected waste would be mandatory.

Since most of the disposable medical items are used by the nursing staff, they could play an important part in the sorting of the plastic at the point of source. This step would be made part of their performance evaluation.

This recycling practice can enhance the burden of plastic on the environment and its acceptable disposal methods can be beneficial for the hospitals as an income-generating stream (Vogt \& Nunes 2014), and revenue generated from the sale of hospital non-infectious waste may be distributed among the nursing staff, which will be an incentivebased policy. This value-added step can bring the desired results of on-source segregation and accounting of hospital waste.

\section{Need for amendments in rules}

Hospital waste management rules 2005 of Pakistan provide information about the segregation of infectious or risk waste from hospital waste, but it does not have any policy regarding the sorting of plastic waste from non-infectious waste. Necessary amendments are needed to be made in these rules regarding the segregation of plastic waste from the non-risk waste at the point of source to reduce the impact of hospital plastic on the health, environment, and economy of the country.

American standards regarding the separation of plastic (especially chlorinated plastic) from hospital waste before its final incineration can be followed to amend local rules (Environmental Protection Agency 2013).

\section{Chemical crosslinking disposal method}

Despite institutional governance issues, some deliberate actions were also observed on the part of sweeping/cleaner staff which promotes illegal segregation of hospital plastic waste. This manhandling leads to the breakage of a chain of proper hospital waste management and resultantly hospital plastic waste drawn from the cycle reaches the hands of illegal recyclers. To curtail this issue, an engineering solution is proposed for the effective handling of hospital plastic waste.

Chemical crosslinking of the hospital plastic waste can be adopted which will make sure that hospital plastic waste leaving the hospital premises will not be reprocessed illegally. According to this method, the plastic content of hospital waste may be shredded and mixed with a suitable crosslinker. After mixing, the blend will be thermally compressed and finally shredded to dispose of the waste using already available incineration and landfill technology or even used for resource-derived fuel (RDF).

Waste shredding technology has been previously combined with other waste treatment technologies such as autoclaves, microwave, and chemical treatment technology to reduce hospital waste volume and to make it unrecognizable (Mukhtar et al. 2017; Pieper et al. 2018; World Health Organization 2019a). However, in the chemical crosslinking method, the shredding and compression technique may be combined with incinerator and landfill technology, as shredding alone does not serve the purpose to prevent hospital plastic waste recycling.

The compression of mixed plastic and crosslinking would make the resulting shredded material non-processable. Onsite incineration of hospital waste is a high-cost treatment technology considering its capital and operational cost 
(World Health Organization 2019a). There is also a growing public concern about the incineration of hospital waste due to the harmful emission of mercury, cadmium, furans, and dioxins (Gautam et al. 2010).

Unlike incineration, this proposed method does not involve any incineration within healthcare premises and provides a cost-effective solution to hospital waste management as it involves simple and small-scale shredding, mixing, and thermal compression (Fig. 4).

\section{Methodology}

First, the hospital plastic waste will be collected from hospitals. After the collection of hospital waste, it will be segregated based on types of polymers, and the amount of each polymer present in it will be recorded. Then segregated plastic will be shredded using a high-speed rotating blade (1750 revolutions per minute) shredder (Spilhaus 1967). The resulting shredded plastic will be blended in a rotary mixer with dicumyl peroxide (DCP). After blending mixed plastic and crosslinking additive, the blend will be thermally compressed using a vertical compression molding machine in crosslinked sheets of mixed plastic. These sheets will be cooled and shredded again using a high-speed rotating blade shredder. Finally, this shredded plastic waste will be sent to incineration or landfill facilities, as illustrated in Fig. 5.

To crosslink plastic blends on a laboratory scale, different approaches have been used in literature. The most commonly used technique to crosslink mixed plastic waste is the mixing of granulated plastic waste with a crosslinking agent and compression molding to prepare samples for testing as shown in Table 3 . That is why mixing the granulated plastic mixture with DCP at temperature $50{ }^{\circ} \mathrm{C}$ and compression molding at $190{ }^{\circ} \mathrm{C}$ for $10 \mathrm{~min}$ at a pressure of 20 bar would be enough to crosslink the mixed plastic.

\section{Choice of crosslinking agent}

Crosslinking agents are most commonly used to modify the properties of thermoplastic. Crosslinking prevents chain movement by joining them together which increases the melt flow index of the polymer (Tamboli et al. 2004).

Peroxide crosslinking is one of the most suitable routes of crosslinking for recycled plastics due to the following reasons.

1. Uniform crosslinking throughout the polymer

\section{Suggestions for reduction of hospital plastic waste in Pakistan}

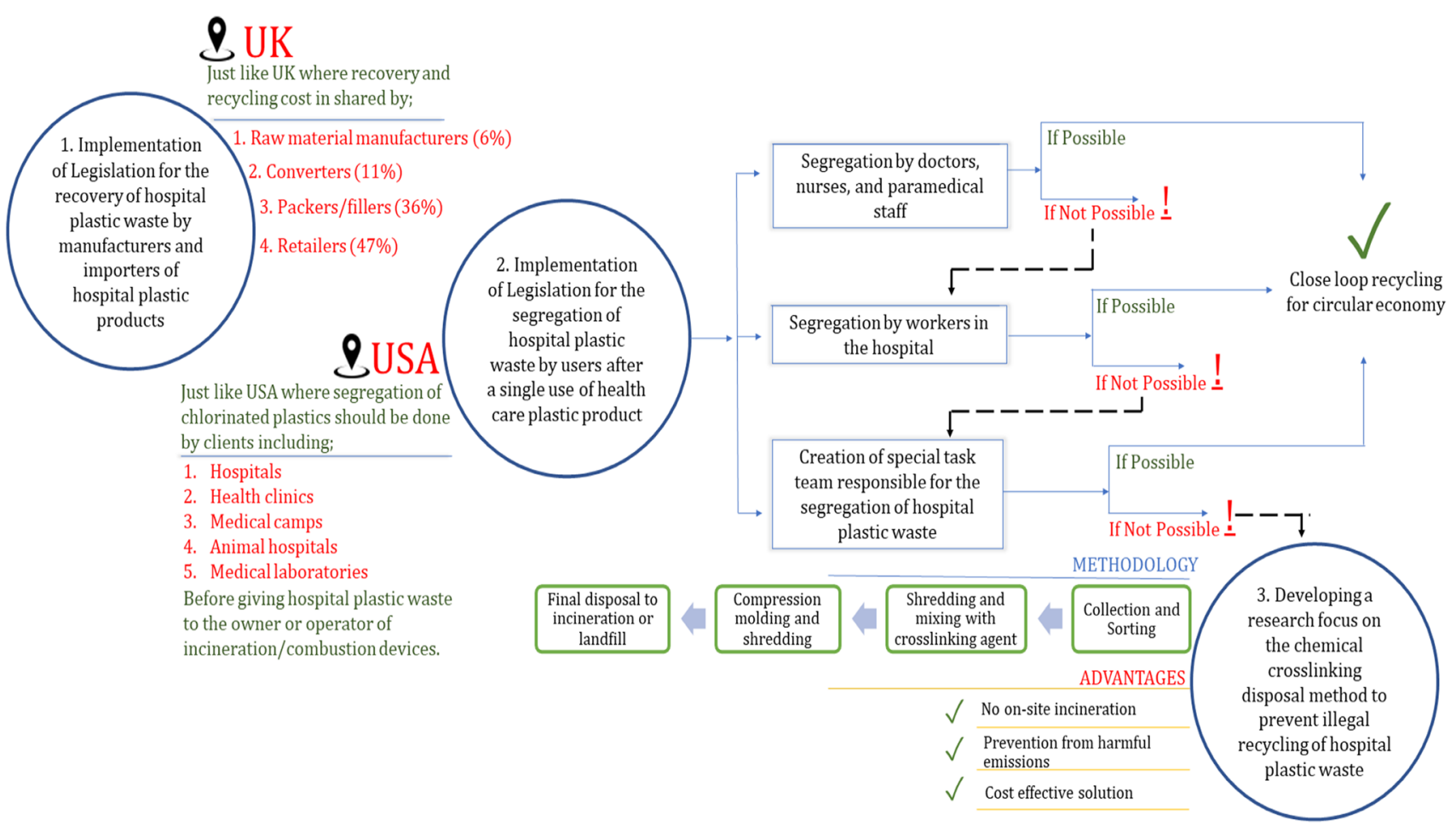

Fig. 4 Suggestions and high potential approach for managing the hospital plastic waste in Pakistan 
Fig. 5 Process flow diagram of the newly proposed disposal method

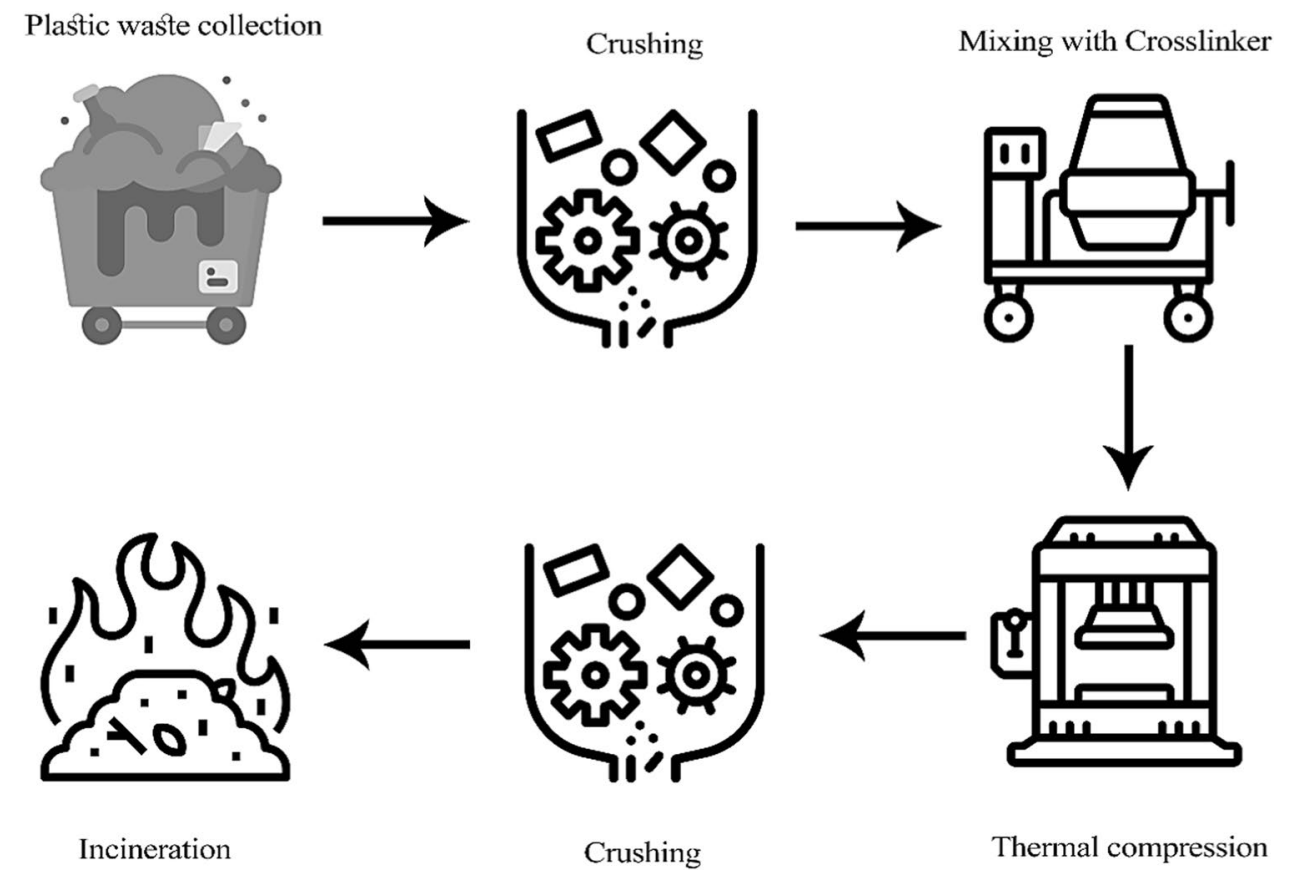

2. Organic peroxide is preferable because of its economic feasibility and easy control of the initiator's decomposition rate

3. Lesser amounts of side products

4. Ease of availability

Dicumyl peroxide (DCP) is one of the most commonly used crosslinking agents for polyolefin due to the highest efficiency of DCP among all other peroxides (Tamboli et al. 2004). It is regarded as the best crosslinking agent for HDPE (Anbarasan et al. 1995). The most commonly used crosslinking agent for polyolefin blends is DCP (Ajji 1996; Chodak et al. 1997; Fuke and Mahanwar 2002; Viksne et al. 2004). Besides the disposal of hospital plastic waste, another feasible option for its treatment is recycling. Upgradation of the properties of recycled plastics is another way for the utilization of plastic waste as a base polymeric material for the fabrication of polymer-based nanocomposites in the field of non-medical applications (Gill et al. 2012, b, c; Mamoor et al. 2014; Vogt and Nunes 2014) Nevertheless, they can be recycled into non-food and non-medical graded items such as coat hanger (Vogt and Nunes 2020). Similarly, IV bags (PVC) which can be $10 \%$ of the total plastic waste are $90 \%$ non-infected and can be recycled (Lee et al. 2021a).

\section{Future prospects}

More obviously, the future load of hospital plastic waste will continue to be disproportionally increased particularly during the COVID-19 pandemic era. In a literal sense, prevailing hospital waste management legal instruments are good at defining the roles of waste generators, collectors, and handlers. However, lessons learned from their implementation suggest that there are technical flaws and hacks which drastically reduce the efficacy of these instruments. One of the major challenges is to fix the issue of hospital plastic waste pilferage. This thorough review leads to technically sound recommendations for updating the polices for minimization of chances of pilferage through a thermochemical approach. We believe that in near future, the implementation of updated policies would lead to a stable ecosystem and can be helpful in coping with the unethical and illegal practices regarding handling of hospital plastic waste. Furthermore, the dataset and suggestions provided in this review can assist the country in achieving its objective of reducing hospital plastic waste. In the future, we intend to recommend the instant interventions to the legislature and Environment Protection Department (EPD) for incorporating in the piece of legislation.

\section{Conclusion}

The present paper highlighted the illegal and unethical practices regarding the hospital's infectious plastic waste that includes open and unsafe dumping in the ocean and land as well as illegal recycling of the hospital plastic waste in Pakistan. Hospital plastic waste being made of pure polymers and low-cost raw material sources for recycling attracts many illegal plastic recyclers who convert them into foodware and children's toys. 
With the spread of COVID-19, usage of disposable plastic protective equipment has increased which is causing the exponential rise in hospital plastic waste in Pakistan. The main disposal methods being used in Pakistan are incineration and landfilling, but these techniques are not followed properly due to several factors. Successful practices of hospital plastic waste handling in developed countries may be followed to improve hospital plastic waste management in Pakistan.

USA and UK hospital plastic waste segregation strategies can prove to be an effective role model for Pakistan. Besides these, a new chemical crosslinking approach has been suggested to curb the illegal recycling of hospital plastic waste. If implemented, this low-cost on-site method could prove a game-changer for hospital plastic waste management in countries like Pakistan.

Author contribution YQG: conceptualization, methodology, validation, formal analysis, investigation, resources, writing — original draft, writing - review and editing, supervision, project administration. MK: conceptualization, methodology, software, formal analysis, investigation, resources, data curation, writing - original draft, visualization. UA: methodology, software, resources, data curation, writing —original draft, writing — editing, visualization. MWI: validation, investigation, writing-review and editing.

\section{Declarations}

Conflict of interest The authors declare no competing interests.

\section{References}

Abdullah MA, Shaikh BT, Ghazanfar H (2021) Curing or causing? HIV/AIDS in health care system of Punjab, Pakistan. PLoS ONE 16(7 July):e0254476. https://doi.org/10.1371/journal.pone.02544 76

Abid U, Gill YQ, Irfan MS, Umer R, Saeed F (2021) Potential applications of polycarbohydrates, lignin, proteins, polyacids, and other renewable materials for the formulation of green elastomers. Int J Biol Macromol 181:1-29. https://doi.org/10.1016/j.ijbiomac. 2021.03.057

Adeosun SO, Lawal GI, Balogun SA, Akpan EI (2012) Review of green polymer nanocomposites. J Miner Mater Charact Eng 11(04):385-416. https://doi.org/10.4236/jmmce.2012.114028

AFP (2020) Gloves and masks litter Middle East amid virus panic. https://www.arabnews.pk/node/1673711/middle-east

Ahmed Bin Hassan, Mubashar Hassan Zia ABK (2020) Knowledge, attitude and practices regarding biomedical waste management among health care professionals of private sector hospitals in Pakistan. Int J Bus Econ Aff 5(6): 272-280. https://doi.org/10. 24088/ijbea-2020-56001

Ajji A (1995) Morphology and mechanical properties of virgin and recycled polyethylene/polyvinyl chloride blends. Polym Eng Sci 35(1):64-71

Alam MM, Sujauddin M, Igbal GMA, Huda SMS (2008) Report: Healthcare waste characterization in Chittagong Medical College Hospital, Bangladesh. Waste Manag Res 26(3):291-296. https://doi.org/10.1177/0734242X07087661 
Ali S, Mahmood U, Malik AU, Aziz F, Naghman RB, Ahmed I, Ullah Malik A, Aziz F, Bin Naghman R, Ahmed I (2015) Current hospital waste management practices in Pakistan: case study and curative measures. Public Health Prev Med 1(3):125-129

Ali M, Wang W, Chaudhry N (2016) Management of wastes from hospitals: a case study in Pakistan. Waste Manag Res 34(1):87-90. https://doi.org/10.1177/0734242X15616474

Altin S, Altin A, Elevli B, Cerit O (2003) Determination of hospital waste composition and disposal methods: a case study. Pol J Environ Stud 12(2):251-255

Alwabr GMA, Al-Mikhlafi AS, Al-Hakimi SA, Dughish MA (2016) Determination of medical waste composition in hospitals of Sana'a city, Yemen. J Appl Sci Environ Manag 20(2):343-347. https://doi.org/10.4314/jasem.v20i2.15

Ammendolia J, Saturno J, Brooks AL, Jacobs S, Jambeck JR (2021) An emerging source of plastic pollution: environmental presence of plastic personal protective equipment (PPE) debris related to COVID-19 in a metropolitan city. Environ Pollut 269:116160. https://doi.org/10.1016/J.ENVPOL.2020.116160

Amsalu A, Worku M, Tadesse E, Shimelis T (2016) The exposure rate to hepatitis $\mathrm{B}$ and $\mathrm{C}$ viruses among medical waste handlers in three government hospitals, southern Ethiopia. Epidemiol Health 38:e2016001. https://doi.org/10.4178/epih/e2016001

Anbarasan R, Babot O, Maillard B (2004) Crosslinking of high-density polyethylene in the presence of organic peroxides. J Appl Polym Sci 93(1):75-81. https://doi.org/10.1002/app.20390

Arafa A, Eshak ES (2020) Medical waste handling and hepatitis B virus infection: a meta-analysis. Am J Infect Control 48(3):316-319. https://doi.org/10.1016/j.ajic.2019.08.011

Arshad N, Nayyar S, Amin F, Mahmood KT (2011) Hospital waste disposal: a review article. J Pharm Sci Res 3(8):1412-1419

Arub, S., Ahmad, S. R., Ashraf, S., Majid, Z., Rahat, S., \& Paracha, R. I. (2020). Assessment of waste generation rate in teaching hospitals of metropolitan city of Pakistan. Civ Eng J (Iran), 6(9), 1809-1821. https://doi.org/10.28991/cej-2020-03091584

Ayub S, Iram M, Arif M (2021) Doctors' perception regarding hospital waste management at Ghurki Hospital, Lahore, Pakistan. J Med Health Sci 15(4):695

Azouz S, Boyll P, Swanson M, Castel N, Maffi T, Rebecca AM (2019) Managing barriers to recycling in the operating room. Am J Surg 217(4):634-638. https://doi.org/10.1016/j.amjsurg.2018.06.020

Badni M, Dharmashree RD (2011) Bio-medical waste management: a review. Medico-Legal Update 11(2):30-32. https://doi.org/10. 5005/johcd-6-3-141

Baris Koltukuz (2015) Preparation of crosslinkable high density polyethylene and polypropylene polyblends

Bidal D (2020) Single-use surgical masks pile up on Hong Kong beaches after COVID-19 outbreak. Oak Bay News. https://www. vicnews.com/news/single-use-surgical-masks-pile-up-on-hongkong-beaches-after-covid-19-outbreak/

Birpinar ME, Bilgili MS, Erdoğan T (2009) Medical waste management in Turkey: a case study of Istanbul. Waste Manag 29(1):445-448. https://doi.org/10.1016/j.wasman.2008.03.015

Bordeianu, Daniela SG, Şaşcîm CLP (2015) Material flow management for treating waste from medical activity. Int J Innov Res Inf Secur 2(9):16-24

Chodak I, Repin H, Bruls W, Janigova I (1996) Chemical modification of polyolefin blends. Macromol Symp 112(1):159-166. https:// doi.org/10.1002/masy.19961120123

Cook TM (2020) Personal protective equipment during the coronavirus disease (COVID) 2019 pandemic - a narrative review. Anaesthesia 75(7):920-927. https://doi.org/10.1111/anae.15071

Das K, Sharma D, Saha S, Satapathy B (2021) From outbreak of COVID-19 to launching of vaccination drive: invigorating single-use plastics, mitigation strategies, and way forward. Environ Sci Pollut Res 28:55811-55845
Department of Environment, United Kindom. The Producer Responsibility Obligations (Packaging Waste) Regulations 1997, www.legislation.gov.uk, (1997)

Desai A, Mukherji A (2001) The evolution of vertically integrated organizations: the role of historical context. Manag Decis 39(3):233-243. https://doi.org/10.1108/EUM0000000005454

Diaz LF, Eggerth LL, Enkhtsetseg S, Savage GM (2008) Characteristics of healthcare wastes. Waste Manag 28(7):1219-1226. https://doi.org/10.1016/j.wasman.2007.04.010

Drury F (2019) Karachi's Clifton Beach swamped by syringes and medical waste - BBC News. https://www.bbc.com/news/worldasia-49562462

El-Ramady H, Brevik EC, Elbasiouny H, Elbehiry F, Amer M, Elsakhawy T, Omara AE-D, Mosa AA, El-Ghamry AM, Abdalla N, Rezes S, Elboraey M, Ezzat A, Eid Y (2021) Planning for disposal of COVID-19 pandemic wastes in developing countries: a review of current challenges. Environ Monit Assess 193(9):592. https://doi.org/10.1007/s10661-021-09350-1

Environmental Protection Agency (2013) Federal Plan Requirements for Hospital/Medical/Infectious Waste Incinerators. https://www. regulations.gov/docket/EPA-HQ-OAR-2011-0405/document

EPD (2014) Punjab hospital waste management rules 2014. Provincial Environmental Protection Department of Punjab. https://epd. punjab.gov.pk/system/files/PunjabHospitalWasteManagementR ules\%2C2014_0.pdf

Faiza Ilyas (2016) Medical waste dumped in open poses serious threat to public health - Pakistan - DAWN.COM. https://www.dawn. com/news/1282049

Feinmann J (2020) PPE: what now for the global supply chain? BMJ 369. https://doi.org/10.1136/BMJ.M1910

Fuke CA, Mahanwar PA (2020) To study the effect of electron beam and chemical crosslink on electrical properties of PP: EPDM: LDPE ternary blends. J Mater Environ Sci 2020(3):389

Gautam V, Thapar R, Sharma M (2010) Biomedical waste management: incineration vs. environmental safety. Indian J Med Microbiol 28(3):191-192. https://doi.org/10.4103/0255-0857.66465

Gill YQ, Ehsan H, Abid U, Sajid M (2019) Effect of nano-susceptor material addition on the microwave sintering of polypropylene. Pak J Engg Appl Sci 24:88-96

Gill YQ, Abid U, Song M (2020a) High performance Nylon12/clay nanocomposites for potential packaging applications. J Appl Polym Sci 137(41):49247. https://doi.org/10.1002/app.49247

Gill YQ, Song M, Abid U (2020b) Permeation characterization and modelling of polyethylene/clay nanocomposites for packaging. Polym Bull 77(7):3749-3765. https://doi.org/10.1007/ s00289-019-02930-9

Gill, Y., Abid, U., Mehmood, U., Ishfaq, A., \& Naqvi, M. (2021). The use of polymer-graphene composites in fuel cell and solar energy. In M. Rahaman, L. Nayak, H. Ibnelwaleed, \& D. Narayan (Eds.), Polymer nanocomposites containing graphene: preparation, properties and applications (1st ed., pp. 425-505). Elsevier. https://doi.org/10.1016/B978-0-12-821639-2.00004-5

Gill YQ, Abid U, Irfan MS, Saeed F, Shakoor A, Firdaus A (2021b) Fabrication, characterization, and machining of polypropylene/ wood flour composites. Arab J Sci Eng 1-11. https://doi.org/10. 1007/s13369-021-05768-4

Gill YQ, Saeed F, Shoukat MH, Irfan MS, Abid U (2021c) A study on the dewaxing behavior of carbon-black-modified LDPE-paraffin wax composites for investment casting applications. Arab J Sci Eng. https://doi.org/10.1007/s13369-021-05406-z

$\mathrm{Gu}$ J, Xu H, Wu C (2013) The effect of PP and peroxide on the properties and morphology of HDPE and HDPE/PP blends. Adv Polym Technol 32(1):1-9. https://doi.org/10.1002/adv.21326

Haddad MB, De-la-Torre GE, Abelouah MR, Hajji S, Alla AA (2021) Personal protective equipment (PPE) pollution associated with the COVID-19 pandemic along the coastline of Agadir. Morocco 
Sci Total Environ 798:149282. https://doi.org/10.1016/J.SCITO TENV.2021.149282

Haque MS, Uddin S, Sayem SM, Mohib KM (2021) Coronavirus disease 2019 (COVID-19) induced waste scenario: a short overview. J Environ Chem Eng 9(1):104660. https://doi.org/10.1016/J. JECE.2020.104660

Islam F (2020) Why a billion items of PPE is not enough. BBC News. https://www.bbc.com/news/business-52362707

Jaffery S (2013) Medical waste illegally sold off from Pakistan hospital. https://www.bbc.com/news/av/world-asia-22130292/medic al-waste-illegally-sold-off-from-pakistan-hospital

Khan BA, Cheng L, Khan AA, Ahmed H (2019) Healthcare waste management in Asian developing countries: a mini review. Waste Manag Res 37(9):863-875. https://doi.org/10.1177/0734242X19 857470

Khonakdar HA, Morshedian J, Wagenknecht U, Jafari SH (2003) An investigation of chemical crosslinking effect on properties of high-density polyethylene. Polymer 44(15):4301-4309. https:// doi.org/10.1016/S0032-3861(03)00363-X

Komilis D, Fouki A, Papadopoulos D (2012) Hazardous medical waste generation rates of different categories of health-care facilities. Waste Manag 32(7):1434-1441. https://doi.org/10.1016/j.wasman.2012.02.015

Krupa I, Luyt AS (2002) Cross-linking of LDPE/wax blends in the presence of dicumyl peroxide. S Afr J Chem 55:34-42

Lee BK, Ellenbecker MJ, Moure-Eraso R (2002) Analyses of the recycling potential of medical plastic wastes. Waste Manag 22(5):461-470. https://doi.org/10.1016/S0956-053X(02)00006-5

Lee BK, Ellenbecker MJ, Moure-Ersaso R (2004) Alternatives for treatment and disposal cost reduction of regulated medical wastes. Waste Manag 24(2):143-151. https://doi.org/10.1016/j. wasman.2003.10.008

Li C-S, Jenq F-T (1993) Physical and chemical composition of hospital waste. Infect Control Hosp Epidemiol 14(3):145-150. https://doi. org/10.2307/30148478

Liu SQ, Gong WG, Zheng BC (2014) The effect of peroxide crosslinking on the properties of low-density polyethylene. J Macromol Sci Part B Phys 53(1):67-77. https://doi.org/10.1080/00222 348.2013.789360

Mahmood S, Mohsin J, Javed H (2011) Practices regarding hospital waste management at public and private sector hospitals of Lahore. Annals 17(2):113-115. https://doi.org/10.1002/(SICI) 1097

Mamoor GM, Irfan MS, Gill YQ, Qaiser AA, Saeed F (2012) Effect of recycled polypropylene on the mechanical and rheological properties of polypropylene-NBR thermoplastic vulcanisates. Progr Rubber Plast Recycl Technol 28(4):189-200. https://doi.org/10. $1177 / 147776061202800404$

Ministry of National Health Services Regulations \& CoordinationGovernment of Pakistan (2020) National Action Plan for Corona virus disease (COVID-19) Pakistan

Modjarrad K, Ebnesajjad S (2013) Handbook of polymer applications in medicine and medical devices. In Handbook of polymer applications in medicine and medical devices (1st ed.). https://doi.org/ 10.1016/C2012-0-07906-9

Mohee R (2005) Medical wastes characterisation in healthcare institutions in Mauritius. Waste Manag 25(6 SPEC. ISS.):575-581. https://doi.org/10.1016/j.wasman.2004.10.003

Mujeeb SA, Adil MM, Altaf A, Hutin Y, Luby S (2003) Recycling of injection equipment in Pakistan. Infect Control Hosp Epidemiol 24(2):145-146. https://doi.org/10.1086/502175

Mukhtar S, Khan H, Kiani Z, Nawaz S, Zulfiqar S, Tabassum N (2018) Hospital waste management: execution in Pakistan and environmental concerns - a review. Environ Contam Rev 1(1):18-23. https://doi.org/10.26480/ecr.01.2018.18.23
Munir S, Adila Batool S, Nawaz Chaudhry M (2014) Characterization of hospital waste in Lahore, Pakistan. Chin Med J 127(9):1732-1736. https://doi.org/10.3760/cma.j.issn.03666999.20132088

Naz S, Naqvi SMZH, Jafry SIA, Asim S (2020) Knowledge, attitude and practice regarding management of health care waste among private dental practitioners. J Pak Med Assoc 70(7):12591262. https://doi.org/10.5455/JPMA.22368

NDMA (2020) Cumulative Logistics Update of (PPE). National Disaster Management Authority. http://web.ndma.gov.pk/Supply.php

Nilay Syam (2020) Is the pandemic triggering a spike in plastic pollution? - CGTN. https://newseu.cgtn.com/news/2020-05-22/Isthe-pandemic-triggering-a-spike-in-plastic-pollution--QBobe agfok/index.html

Oweis R, Al-Widyan M, Al-Limoon O (2005) Medical waste management in Jordan: a study at the King Hussein Medical Center. Waste Manag 25(6 SPEC. ISS.):622-625. https://doi.org/10. 1016/j.wasman.2005.03.011

Patwary MA, O'Hare WT, Sarker MH (2011) An illicit economy: scavenging and recycling of medical waste. J Environ Manag 92(11):2900-2906. https://doi.org/10.1016/j.jenvman.2011.06. 051

Pieper U, Hayter A, Montgomery M (2017) Safe management of wastes from health-care activities: a summary. In: World Health Organisation (Issue WHO/FWC/WSH/17.05). WHO/FWC/WSH/17.05

Prem Ananth A, Prashanthini V, Visvanathan C (2010) Healthcare waste management in Asia. Waste Manag 30(1):154-161. https:// doi.org/10.1016/j.wasman.2009.07.018

Producer Responsibility Obligations (Packaging Waste) Regulations 1997, Statutory Instrument 1997 No. 6481 (1999)

Qadir S, Naeem Akhtar M, Ul Hassan M, Ahmad I, Naeem H, Ur Rehman O (2014) Study of hospital waste disposal practice in a tertiary care hospital. Gomal J Med 12(2):64-67

Rai P, Roy D (2021) Death and scarcity of life saving ppes: where is the life of heroes? Asian J Nurs Educ Res 11(1):157-160. https:// doi.org/10.5958/2349-2996.2021.00040.9

Randhawa S (2018) Recycling of hospital waste into different products continues unchecked in Lahore. Pakistan Today. https://www. pakistantoday.com.pk/2018/01/23/recycling-of-hospital-wasteinto-different-products-continues-unchecked-in-lahore/

Salernitano E, Migliaresi C (2003) Composite materials for biomedical applications: a review. J Appl Biomater Biomech 1(1):3-18. https://doi.org/10.1177/228080000300100102

Sangkham S (2020) Face mask and medical waste disposal during the novel COVID-19 pandemic in Asia. Case Stud Chem Environ Eng 2(September):100052. https://doi.org/10.1016/j.cscee.2020. 100052

Sarkodie SA, Owusu PA (2021) Impact of COVID-19 pandemic on waste management. Environ Dev Sustain 23(5):7951-7960. https://doi.org/10.1007/s10668-020-00956-y

Sastri VR (2013) Plastics in medical devices: properties, requirements, and applications: second edition. In: Ebnesajjad S (ed) Plastics in medical devices: properties, requirements, and applications: second edition. Elsevier Inc. https://doi.org/10.1016/ C2012-0-05946-7

Sawalem M, Selic E, Herbell JD (2009) Hospital waste management in Libya: a case study. Waste Manag 29(4):1370-1375. https:// doi.org/10.1016/j.wasman.2008.08.028

Singh N, Tang Y, Ogunseitan OA (2020) Environmentally sustainable management of used personal protective equipment. Environ Sci Technol 54(14):8500-8502. https://doi.org/10.1021/acs.est. 0c03022

Spilhaus A (1967) Waste management and control. Sci Citizen 9(910):219-223. https://doi.org/10.1080/21551278.1967.10114792

Strashok C, Dale A, Herbert Y, Foon R (2010) Greening Canadian hospitals. Community Research Connections, August, 22 
Taghipour H, Mosaferi M (2009) Characterization of medical waste from hospitals in Tabriz, Iran. Sci Total Environ 407(5):15271535. https://doi.org/10.1016/j.scitotenv.2008.11.032

Tamboli SM, Mhaske ST, Kale DD (2004) Crosslinked polyethylene. Indian J Chem Technol 11(6):853-864. https://doi.org/10.1142/ 9781783267170_0006

Tiwari A (2014) Biomedical waste management practices in India-a review. International Journal of Current Engineering and Technology, May, 2030-2033

Toheed R, Ayub TB, Mumtaz S, Mehr AR (2016) Hospital waste management in teaching hospitals of Lahore system assessment using new tool. Pak J Med Health Sci 10(2):377-379

Viksne A, Malers L, Bledzki AK (1997) Mechanical properties-structure relationships of crosslinked blends based on LDPE/HDPE waste. Angew Makromol Chem 249(1):47-57. https://doi.org/ 10.1002/apmc. 1997.052490104

Vinyl Council of Australia (2018) PVC recycling in hospitals. https:// www.vinyl.org.au/pvc-recycling-in-hospitals

Vogt J, Nunes KRA (2014) Recycling behaviour in healthcare: waste handling at work. Ergonomics 57(4):525-535. https://doi.org/10. 1080/00140139.2014.887786

Voudrias E, Goudakou L, Kermenidou M, Softa A (2012) Composition and production rate of pharmaceutical and chemical waste from Xanthi General Hospital in Greece. Waste Manag 32(7):14421452. https://doi.org/10.1016/j.wasman.2012.01.027

Wang J, Shen J, Ye D, Yan X, Zhang Y, Yang W, Li X, Wang J, Zhang L, Pan L (2020) Disinfection technology of hospital wastes and wastewater: suggestions for disinfection strategy during coronavirus disease 2019 (COVID-19) pandemic in China. Environ Pollut 262:114665. https://doi.org/10.1016/j.envpol.2020.114665

Wong KFV, Narasimhan R, Kashyap R, Fu J (1994) Medical waste characterization. J Environ Health 57(1):19-25

World Health Organization (2019a) Overview of technologies for the treatment of infectious and sharp waste from health care facilities. World Health Organization; World Health Organization. https://apps.who.int/iris/handle/10665/328146

World Health Organization (WHO) (2019b) WASH in health care facilities. World Health Organization (WHO). https://www.who.int/ publications/i/item/9789241515511

World Health Organization (WHO) (2020a) Advice on the use of masks in the community, during home care and in healthcare settings in the context of the novel coronavirus (2019-nCoV) outbreak: interim guidance. (2020). Geneva: World Health Organization (Vol. 2020, Issue January)

World Health Organization (WHO) (2020b) Water, sanitation, hygiene and waste management for the COVID-19 virus. World Health Organisation. https://apps.who.int/iris/handle/10665/331499

Yu H, Sun X, Solvang WD, Zhao X (2020) Reverse logistics network design for effective management of medical waste in epidemic outbreaks: insights from the coronavirus disease 2019 (COVID19) outbreak in Wuhan (China). Int J Environ Res Public Health 17(5):1770. https://doi.org/10.3390/ijerph17051770

Zagho MM, Hussein EA, Elzatahry AA (2018) Recent overviews in functional polymer composites for biomedical applications. Polymers (Basel) 10(7):739. https://doi.org/10.3390/polym10070739

Zeeshan MF, Al Ibad A, Aziz A, Subhani A, Shah A, Khan T, Ullah H, Qazi U (2018) Practice and enforcement of national hospital waste management 2005 rules in Pakistan. East Mediterr Health J 24(5): 443-450. https://doi.org/10.26719/2018.24.5.443

Zeng X, Wu C, Tang B, Shen X, Liu K, Ye B, Jia Y (2020) Spray-free polypropylene composite reinforced by graphene oxide@ short glass fiber. Polym Compos 41(4):1215-1223. https://doi.org/10. $1002 /$ pc. 25447

Publisher's note Springer Nature remains neutral with regard to jurisdictional claims in published maps and institutional affiliations. 